\title{
FIRST REPORT OF POTATO VIRUSES INFECTING LAMIUM PURPUREUM IN UKRAINE
}

\author{
A.M. Kyrychenko ${ }^{1}$, M.M. Bohdan ${ }^{1}$, H.O. Snihur ${ }^{1,2}$, \\ I.S. Shcherbatenko ${ }^{1}$, I.O. Antipov ${ }^{3}$ \\ 'Zabolotny Institute of Microbiology and Virology, NAS of Ukraine, \\ 154 Acad. Zabolotny Str., Kyiv, 03143, Ukraine \\ ${ }^{2}$ Taras Shevchenko National University, \\ ESC "Institute of Biology and Medicine", Virology Department, \\ 64/13 Volodymyrska Str., Kyiv, 01601, Ukraine \\ ${ }^{3}$ National University of Life and Environmental Sciences of Ukraine, \\ Department of molecular biology, microbiology and biosafety, \\ 15 Heroyiv Oborony Str., Kyiv, 03041, Ukraine \\ e-mail:kirangel.07@meta.ua
}

Introduction. Weeds as reservoirs for destructive plant pathogens have a significant impact on the viral epidemiology, ecology and, as a result, on local economy, and are therefore being investigated in many parts of the world. Thus, the aim of this study was to investigate virus occurrence in red dead-nettle plants (Lamium purpureum L.) widespread in urban and field conditions throughout the in the Kyiv region of Ukraine. Methods. Field crop observations, visual diagnosis, biological testing of the virus, immunoassay (ELISA), polymerase chain reaction with reverse transcription (RT-PCR), sanger sequencing of partial genome sequences of PVX, PVY, PVS, PVM. Results. The results obtained in the study indicate that Lamium plants could be alternative weed hosts of number important viral diseases including potatoes and other vegetables. Serological and molecular test results evidence plants were infected by Potato virus $X$, Potato virus $Y$, Potato virus $M$, Potato virus $S$ and therefore Lamium L. species can serve as a potential source of inoculum for wide range of vegetables and ornamentals. This study is the first report of Lamium plants being naturally infected with Potato virus $M$ and Potato virus $S$ in central Europe. Conclusions. These plants are alternative host of mixed infection with viruses belonging to different families: Alphaflexiviridae, Betaflexiviridae and Potyviridae.

Keywords: Lamium purpureum L., red dead-nettle, alternative hosts, Potato virus X, Potato virus Y, Potato virus $M$, Potato virus $S$.

The fact that weeds as well as generally of the wild plants can be alternative hosts and sources of important plant viruses have been known since the beginning of plant virology [1]. Since the new possibilities of metagenomic analysis, it became clear that the variety of viruses in natural settings is much greater than in cultivated plants, and the role of wild plants in the evolution and ecology of viruses are much underestimated. One of the alternative hosts of these economically important viruses can be plants of the Lamium species.

Lamium L. (dead-nettle) is a genus of herbaceous plants comprising approximately 40 species native to Europe, Asia, and North Africa [2]. They are mostly annual or perennial plants that often cover roadsides, debris, ditches and grow in the forests and shrubs, as weeds in gardens and orchards. The plants are widespread in Ukraine, except the southern steppe. The most distributed lamium species is white deaf-nettle (Lamium album L.) popular honey and medicinal plant. Another fairly common plant is Lamium purpureum L. (red deadnettle). In addition, five other species of this genus are common in Ukraine: Lamium amplexicaule L., Lamium galeobdolon L., Lamium orvala L. and Lamium maculatum L. Lamium glaberrimum (K. Koch) Taliev growing in Crimea, belongs to the endangered species and listed in the Red Book of Ukraine in the status of «rare». In addition to the listed species, many varieties are cultivated in Ukraine as excellent ground cover plants and, together with wild species, for decorative purposes. For understanding the range of viruses that can infect these plants we have analyzed the scientific literature relevant up to date. Five Lamium species, possible reservoirs for viruses belonging to 
Bromoviridae, Caulimoviridae, Geminiviridae, Tospoviridae, Potyviridae, Alphaflexiviridae and Secoviridae families (Table 1) has been found.

Having analyzed the range of viruses naturally infecting Lamium plants, we focused mainly on the viruses of vegetable crops widespread in Ukraine, in particular on AMV, CMV, TuMV, TSWV, WMV, PVX and PVY. So, the aim of the study was to determine the involvement of the above-mentioned viruses in the infection of red dead-nettle (Lamium purpureum L.) under natural conditions of Kyiv region of Ukraine and to identify the causative agents of infection of these weeds.

\section{Methods}

Sample collection. Plant sampling was conducted during summer and autumn seasons of 2020 and 2021 years. Samples exhibiting suggestive symptoms of viral infection were collected from the urban environment of Kyiv and in the vicinity of potato fields of Kyiv regions. Leaves from symptomatic Lamium plants were analyzed by enzyme-linked-immunosorbent assay (ELISA) or reverse transcription polymerase chain reaction (RT-PCR). By these methods the samples were tested for the presence of Cucumber mosaic virus (CMV), Tomato spotted wilt virus (TSWV), Potato virus X (PVX), Potato virus Y (PVY), Potato virus $\mathrm{M}$ (PVM), Potato virus S (PVS), Potato virus A (PVA) and Alfalfa mosaic virus (AMV).

DAS-ELISA testing. Serological identification of the viruses was performed using commercial ELISA kits (LOEWE Biochemica $\mathrm{GmbH}$, Sauerlach, Germany) according to the manufacturer's guidelines. Absorbance values were measured at $405 \mathrm{~nm}$ with a microplate reader (Dynatech ELISA reader, USA). A result was considered positive if the OD value was $\geq 0.2$.

RT-PCR. Plant specimens of Lamium purpureum collected for virus detection and identification as well as indicator plants were tested by RT-PCR for the presence of PVX, PVY, PVM, PVS, PVA and AMV. Total RNA was extracted from $0.5 \mathrm{~g}$ of leaf tissue by a previously reported method [3]. The RT was performed using Reverta kits (AmpliSens), according to the manufacturer's instruction.

The primer pairs for viruses detecting were designed from representative virus genome sequences deposited in the National Center for Biotechnology Information (NCBI) using Primer Express (Applied Biosystems) software. Primers amplify the partial coat protein $(\mathrm{CP})$ gene were used for both amplification and sequencing $[4,5]$.

For PCR, $2 \mu \mathrm{L}$ of the template genomic DNA was amplified in a $25-\mu \mathrm{L}$ of total volume containing $1 \times$ reaction buffer, 5 pmol of each primer, 0.3 $\mathrm{mM}$ dNTPs, $1.25 \mathrm{U}$ of TaqDNA polymerase and nuclease-free water.

Reactions were performed under the following conditions: 3 min denaturation at $95{ }^{\circ} \mathrm{C}$, thermal cycling for 35 cycles $\left(1 \mathrm{~min}\right.$ at $94{ }^{\circ} \mathrm{C}, 1 \mathrm{~min}$ at $60{ }^{\circ} \mathrm{C}$ and 1 min $30 \mathrm{~s}$ at $72{ }^{\circ} \mathrm{C}$ ), ending with the final extension at $72{ }^{\circ} \mathrm{C}$ for $5 \mathrm{~min}$. PCR products

Table 1

Plant viruses naturally infected Lamium species

\begin{tabular}{|c|c|c|}
\hline Lamium species & Virus & References \\
\hline \multirow{2}{*}{ Lamium maculatum } & Cucumber mosaic virus (CMV), Bromoviridae & [24] \\
\hline & Lamium leaf distortion associated virus (LLDAV), Caulimoviridae & [37] \\
\hline \multirow{5}{*}{ Lamium amplexicaule } & $\begin{array}{l}\text { Alfalfa mosaic virus (AMV), Bromoviridae; Turnip mosaic } \\
\text { virus (TuMV), Potyviridae; Watermelon mosaic virus (WMV), } \\
\text { Potyviridae; Cucumber mosaic virus (CMV), Bromoviridae }\end{array}$ & [38] \\
\hline & Tomato yellow leaf curl virus (TYLCV), Geminiviridae & [29] \\
\hline & Tomato spotted wilt virus (TSWV), Tospoviridae & {$[26,28,34]$} \\
\hline & Melon yellow spot virus (MYSV), Tospoviridae & [36] \\
\hline & Potato virus $Y$ (PVY), Potyviridae & [17] \\
\hline \multirow{6}{*}{$\begin{array}{l}\text { Lamium purpureum, } \\
\text { Lamium purpureum } \\
\text { var. hybridum (Vill.) }\end{array}$} & Potato virus $Y$ (PVY), Potyviridae & [16] \\
\hline & Potato virus $X(\mathrm{PVX})$, Alphaflexiviridae & [18] \\
\hline & Cucumber mosaic virus (CMV), Bromoviridae & {$[35,38]$} \\
\hline & Tomato spotted wilt virus (TSWV), Tospoviridae & {$[25,32]$} \\
\hline & Beet yellow virus (BYV), Closteroviridae & [27] \\
\hline & Tobacco mosaic virus (TMV), Virgaviridae & [27] \\
\hline Lamium album & Lamium mild mosaic virus (LMMV), Secoviridae & {$[30,33]$} \\
\hline Lamium orvala & Lamium mild mosaic virus (LMMV), Secoviridae & {$[30,31]$} \\
\hline
\end{tabular}


of amplification were visualized in $1.5 \%$ agarose gels with TBE buffer and ethidium bromide (0.5 $\left.\mathrm{mg} \mathrm{mL}^{-1}\right)$.

Biological assays. Plants of Lamium maculatum (cv Pink Pewter) Chenopodium amaranticolor, Chenopodium album, Gomphrena globosa, Datura metel, Datura stramonium, Capsicum annuum (cv Obriy), Solanum lycopersicum, Nicotiana tabacum (var. Trapezond 92), Solanum tuberosum (cv Bellarosa), Solanum nigrum for bioassay were maintained in greenhouse at $22-$ $26{ }^{\circ} \mathrm{C}$ and used for mechanical inoculation. In all, 10 plants of each indicator plant species were tested. Carborundum-dusted leaves of healthy indicator plants were rubinoculated using crude sap extracts of infected leaf tissue prepared in $0.01 \mathrm{M}$ phosphate buffer ( $\mathrm{pH}$ 7.4). Both inoculated and mock-treated (control) plants were tested by PCR 5 weeks post-inoculation.

Transmission electron microscopy (TEM). Clarified crude leaf extracts from infected plants were tested by TEM (JEM 1400, JEOL Ltd., Japan). Carbon coated formvar grids after adsorption of virus particles and water washing were stained with either $1 \%$ uranyl acetate [6].

Sequence analysis. The amplified DNAs were sequenced by Sanger dideoxy sequencing method using the BigDye Terminator Cycle Sequencing Kit (Applied Biosystems, USA). The samples were run on the ABI Prism 3130 Genetic Analyzer (Applied Biosystems, USA). Obtained sequences were compared with those available in GeneBank using the BLAST, CLUSTALW and MEGA-X softwares. Sequence photograms were constructed by Neighbor-Joining method [7] and Jukes-Cantor model [8] using MEGA-X in a bootstrap test with 1000 replicates.
Results. During 2020-2021 in central region of Ukraine a survey with aim to find out what natural weeds or wild plants can act as natural virus reservoirs for transmission by vectors was carried out. Lamium purpureum L. plants growing in the urban environment and in natural ecosystems (nearby potato plantations) with characteristic symptoms of the disease were collected for laboratory plant virus detection. Plants selected for analysis from different locations of the Kyiv region differed in the symptoms they produced. Thus, plants growing near farmlands showed symptoms of mosaic, discoloration, chlorosis of leaf blade, vein yellowing (the leaves were smooth, not deformed) and growth reduction (Fig. 1a) whereas plants from urban environment exhibited leaf blade deformations of varying severity, mosaic symptoms and chlorosis of the leaves accompanied by purple leaf spotting (Fig. 1b). Diseased plants were not stunted, but had a slight shortening of the internodes.

By the results of DAS-ELISA testing Cucumber mosaic virus and Tomato spotted wilt virus were not detected in all samples taken from the Lamium purpureum. At the same time, the RT-PCR detection results showed that Lamium purpureum growing in natural settings are co-infected with PVM, PVS, PVX and PVY viruses whereas no PVY was detected in plants growing in urban environment (Fig. 2). The expected sizes of amplifying DNA fragments were: for PVX - 411-base pair (bp), for PVY - 365 bp, for PVM and PVS - 276 bp and 213 bp, respectively. PCR amplification products were not observed from all the infected samples tested using specific primers for PVA and AMV (the data is not presented).
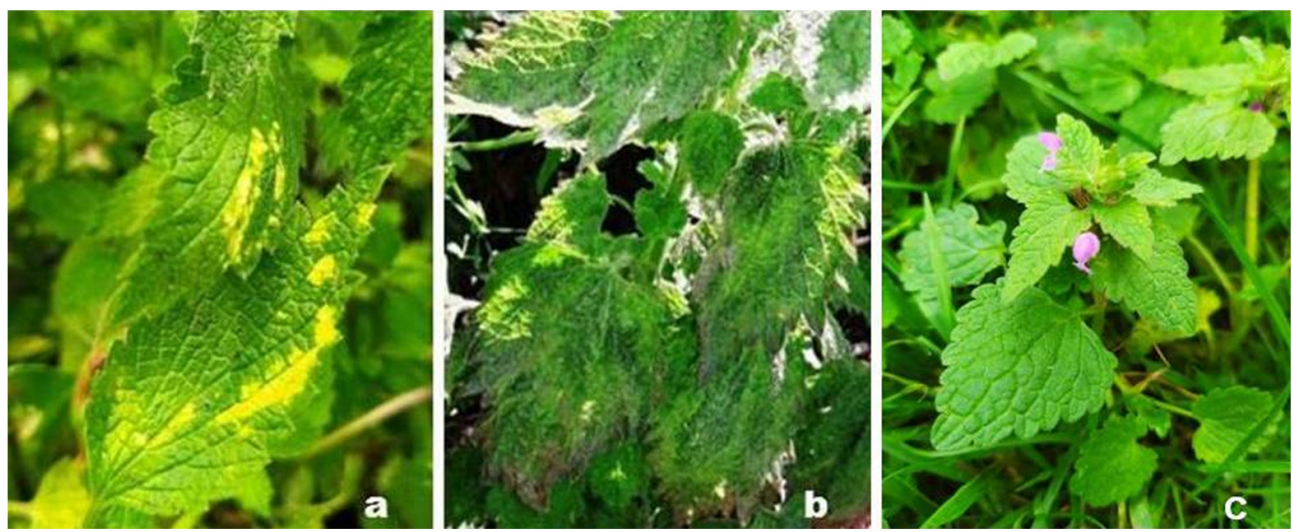

Fig. 1. Symptoms of virus infection in Lamium purpureum growing in natural settings (a) and urban environment (b); $c$ - healthy plants 
Host reactions. The inoculated Gomphrena globosa, Capsicum annum, Datura metel and Chenopodium amaranticolor plants displayed symptoms which could suggest infection with PVX and PVY. None of the Lamium maculatum (cv Pink Pewter) plants showed any symptoms of virus infection. Unfortunately, no symptoms typical for PVM and PVS viruses developed in test plants up to 12 weeks post inoculation were observed, and the viruses were not detected by RT-PCR in these plants that can be explained by the rather low concentration of these viruses in the inoculum.

Potato plants reacted to artificial inoculation with a virus-containing extract by appearance of brown or black (necrotic) line patterns on veins and in the corners between them, mainly on the underside. Necrotic lesions on leaves firstly appeared on inoculated lower leaves, then - on the apical ones. Over time, dark brown spots spread to petioles and stems and by the end of the growing season almost all the leaves were drying up. Since infection of PVM and PVS is usually asymptomatic and PVX cause a mild mosaic with slight leaf crinkling or produce no visible symptoms it is clear that symptoms expressed are affected by mixed infections or are determined by the PVY strain and the potato variety [9-11].

As have been previously reported plants positive for PVY or PVM antigens exhibit a wide range of symptoms: mosaic pattern, stunted growth, yellow spots, veinclearing, and leaf distortion symptoms on Solanum nigrum (black nightshade) plants [12-14]. According to our observations, the abovementioned symptoms on virus-infected black nightshade plants did not appear, whereas plants exhibited foliar symptoms like chlorosis and purple vein coloring on inoculated leaf.

Electron microscopy. Flexuous particles with a size of approximate 550 (Fig. 4a) and $1400 \mathrm{~nm}$ (two adjacent virion aggregates end-to-end) (Fig. 4b) were observed by transmission electron microscopy in negatively stained partially purified leaf tissue

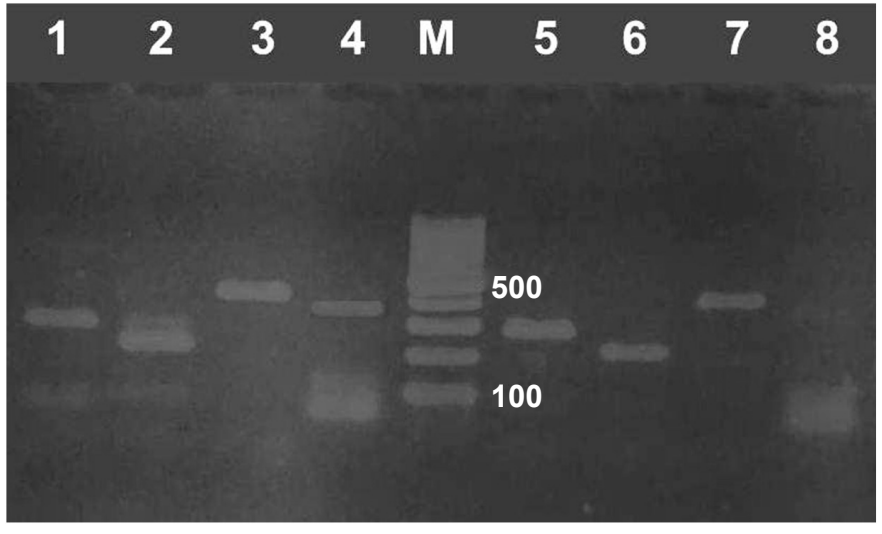

Fig. 2. RT-PCR detection of PVM, PVS, PVX and PVY viruses in Lamium purpureum growing in natural settings (1-4) and urban environment (5-8): Lane 1, 5 - PVM; Lane 2, 6 - PVS; Lane 3, 7 - PVX; Lane 4 - PVY; M - 100 kb Plus DNA ladder (Invitrogen)
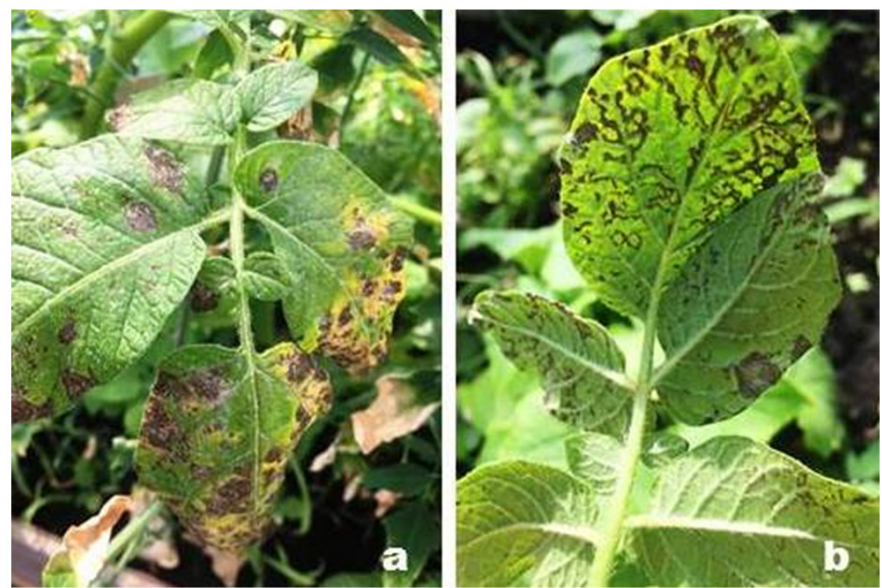

Fig. 3. Solanum tuberosum showing viral symptoms (necrotic lesions, mottling and veinal necrosis) after artificial inoculation with sap extracts of infected red dead-nettle 


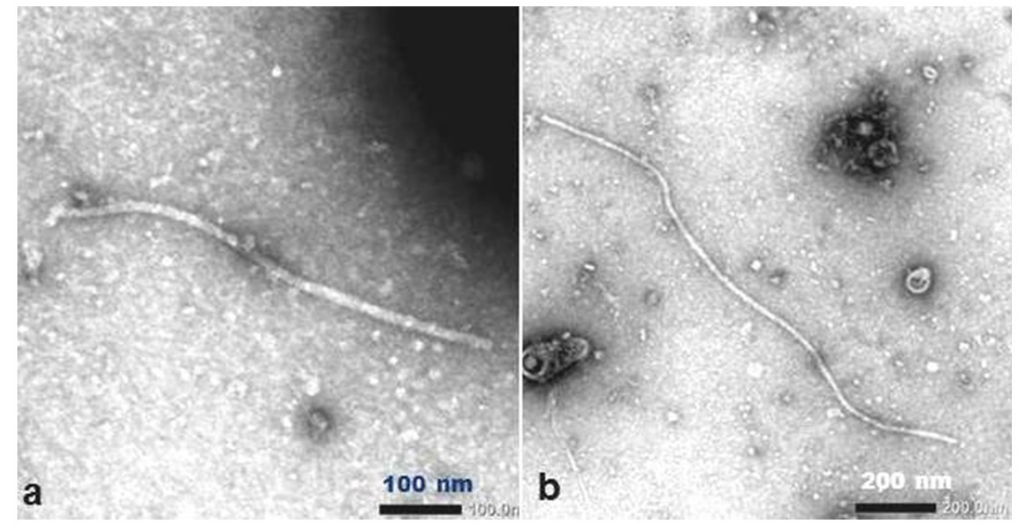

Fig. 4. PVX (a) and PVY (b) virions negatively stained with uranile acetate. Scale bar represents 100 (a) or 200 (b) $\mathrm{nm}$

extracts from symptomatic Lamium purpureum plants. Morphology of these virus particles is similar to the viruses in the genus Carlavirus (a), Potyvirus (b) and Potexvirus (c). There were no particles in preparations from asymptomatic plants.

Phylogenetic relationships of PVS, PVM, PVX and PVY isolates. To determine the genetic relationships among isolates obtained in the study of phylogenetic trees have been constructed on the base of partial CP nucleotide sequences for each virus isolate, respectively. In phylogenetic tree PVM Lp isolate fell into one group with GQ496609, LC511897, DQ883806 and was closely related to a M34 isolate of India (GenBank accession no. KF471070) (Fig. 5a). The similarity in the identities of the PVM Lp and Ukrainian isolate «Chernigov 06» (GenBank accession no. DQ883806) was amounted to $96.2 \%$.

BLAST search against the complete nucleotide collection at GenBank revealed that PVS Lp is closely related to the Os-11-PVS, Hamedan4 potato isolates from Iran (GenBank accession no. KY523842, LN794162, respectively) and 18$1146,18-1133$ potato isolates from South Africa (GenBank accession no. LN794162, MN689455, respectively) (Fig. 5b). Phylogenetic analysis showed that PVS from this study clustered with PVS163 isolate of Bangladesh (GenBank accession no. MF503889). The similarity in the identities of the PVS Lp and Ukrainian PVS isolates (LN851194 and LN851192, LN851193) was about $94.1 \%$, whereas to the isolate of Bangladesh the identity was almost $96 \%$.

PVX was closely related to Ica027-3 isolate of Peru (GenBank accession no. MT752763) and Potato virus $\mathrm{X}$ isolate Chernigov 06, isolated from potato plants cultivated in Ukraine [15] (GenBank accession no. EF043534) (Fig. 6a). The nucleotide sequence identity among Ukrainian isolates obtained in 2006 and 2020 was more than $96 \%$. The obtained results give reason to believe that the PVX isolate affecting potato crops for more than 15 years circulates in the agro-ecosystem in both cultivated potato plants and wild flora.

Based on the partial genome sequence of PVY Lp and the NCBI database, the BLAST results revealed that PVY Lp has the highest homology (99.1 \%) with PVY 2C15-6 (GenBank accession no. MN414581) obtained from France, Egyptian isolate p14 (GenBank accession no. MN370455) and Ireland PVY P221b (GenBank accession no. MT264737) (Fig. 6b). PVY Lp formed a distinct viral cluster with these viruses what confirms its close relationship with isolates identified in potato crops.

Discussion. To date, there are only a few reports on the possibility of dead-nettles to be a host for PVY [16, 17] and PVX [18]. These studies concerned with single virus infection and nothing is reported about the possibility of a mixed infection in Lamium sp. plants. The results obtained in the our current study showed that, the Lamium purpureum L. as a type species of Lamium (dead-nettles) genus are alternative host of mixed infection with viruses belonging to different families Alphaflexiviridae, Betaflexiviridae and Potyviridae. It was previously indicated that the plants after inoculation with PVY or PVX remained asymptomatic or showed various systemic symptoms (there is no precise description of the symptoms in the articles) [1618]. Therefore, it is difficult to draw conclusions about whether the observed in our study symptoms are caused by an individual viral species or are 
outcomes of interactions between causative viral agents. However, there is evidence of multiple infections of potato with PVX, PVY, PVS, PVM, PVA and Potato leaf roll virus (PLRV), where PVY, PVS and PVX in mixed infections were the most prevalent [19]. It was also reported that mixed infections involving three or even four viruses were detected in $5 \%$ of the potato plants [20]. According to some date, co-infection with several viruses suggests a synergistic interaction and increase disease epidemics as compared to single infection [21]. Although available data are scarce to properly address whether single or mixed infection is causing the symptoms we detected, it is quite clear that each «competitor» benefits from such virus-virus interactions.

Lamium purpureum observed in our study can serve as reservoirs of the complexs potato viruses and play a role as primary sources of infection for vector transmission. Natural vectors of the PVY can be 30 species of aphids, for nine of which (Aphis fabae, Aphis gossypii, Brachycaudus lamii, Cryptomyzus ballotae, Cryptomyzus galeopsidis, Macrosiphum euphorbiae, Rhopalosiphoninus latysiphon, Myzus ornatus, Myzus persicae) the Lamium species are the hosts. Four of the currently known vectors of potato virus A - Aulacorthum solani, Aphis fabae, Aphis frangulae, Macrosiphum euphorbiae colonize dead-nettles [21, 22]. Noncolonizing aphids have been reported to vector PVY and PVA with variable efficiency to a large number of solanaceous and non-solanaceous plant species including weeds and ornamentals [23]. Thus, plants, growing among crops and being infected with these viruses, can act as a source of viral infection for neighboring crops. These results must be taken into account when developing virus control strategies, especially because of the
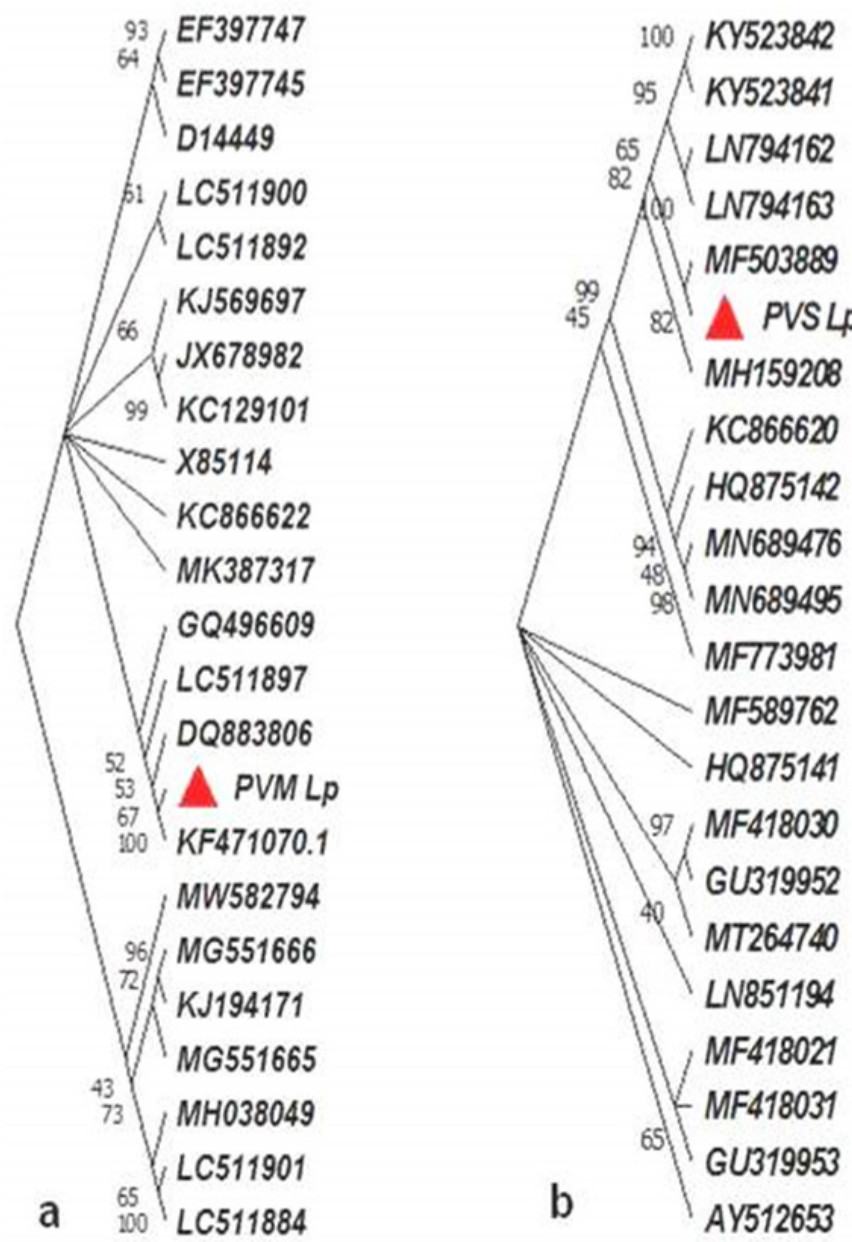

Fig. 5. Phylogenetic analysis of Potato virus $M$ (a) and Potato virus $\mathbf{S}$ (b) detected from Lamium sp. based on the coat protein gene sequences (nt) of different selected isolates from the NCBI database. The phylogenetic tree was generated by MEGAX using neighbor-joining method with 1000 bootstrap replicates 

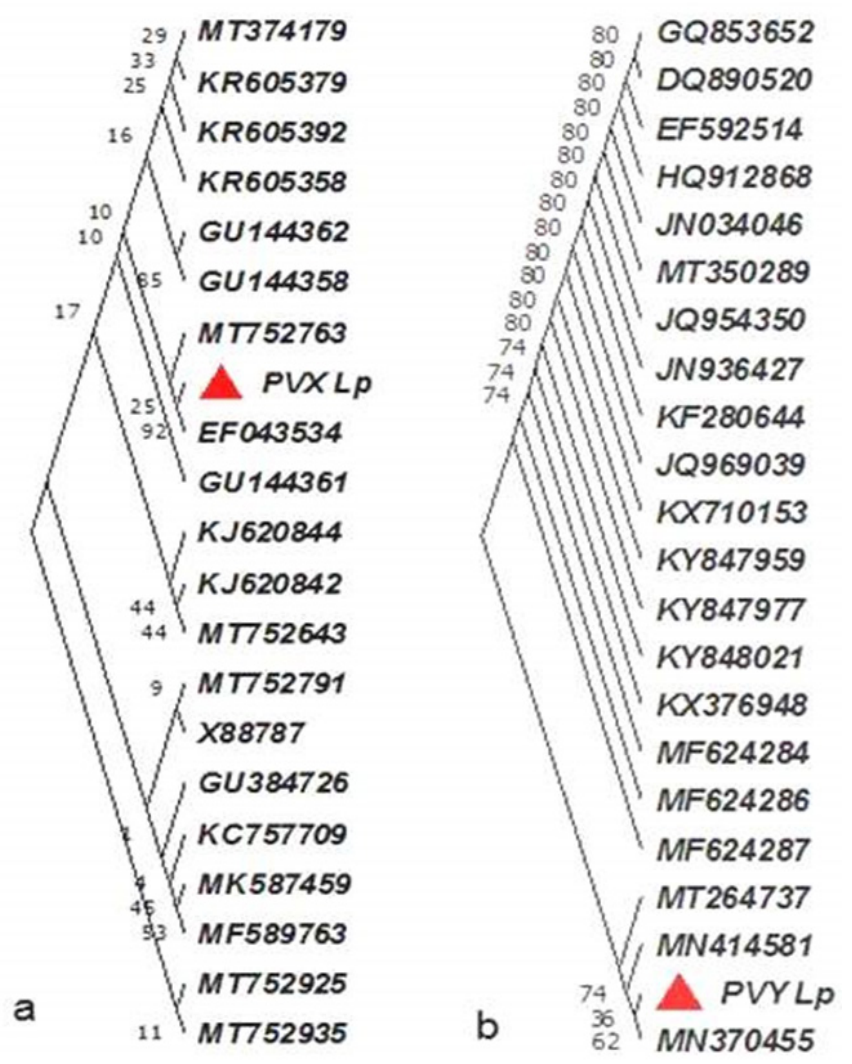

Fig. 6. Phylogenetic analysis of Potato virus X (a) and Potato virus Y (b) detected from Lamium sp. based on the coat protein gene sequences (nt) of different selected isolates from the NCBI database. The phylogenetic tree was generated by MEGAX using neighbor-joining method with 1000 bootstrap replicates

important role of these hosts in providing sources of viruses for aphid vectors. In addition, the data of this study can be used in genetic studies of the relationship of viruses of different taxa in one plant. The complexity of the issue conditioned by lacking of sufficient data about crop-infecting viruses undergoing recombination in wild native plants and the possible changing of virus pathogenic properties under the multiple co-infection. Mechanisms of plant resistance, which in the study are obviously different from the phenomena of antagonism between viruses or their interference, are incomprehensible. Also, it is poorly understood what risks of such co-infection exist for cultivated Solanaceae species often grow side by side in the same ecosystem with weeds. All these questions are subject for further study and explanation.
To the best of our knowledge, this is the first report of Lamium plants being naturally infected with Potato virus $\mathrm{M}$ and Potato virus $\mathrm{S}$ in Ukraine and central Europe. The primers developed by us for the PVX, PVY, PVS and PVM detection and used in the study can be recommended for the rapid screening of potato tubers and the virus diagnostics.

Acknowledgment. The authors express their sincere gratitude to $\mathrm{PhD}$ M.S. Kharchuk (Center of collective usage of the NAS of Ukraine) for his help in conducting microscopic examinations.

Funding. This work was carried out predominantly with funds supplied by the National Academy of Sciences of Ukraine (governmental registration number of the work is 0120U000221). 
ПЕРШЕ ПОВІДОМЛЕННЯ ПРО ІНФIКУВАННЯ LAMIUM PURPUREUM ВІРУСАМИ КАРТОПЛІ В УКРӒ̈НІ

А.М. Кириченко ${ }^{1}$ М.М. Богдан ${ }^{1}$, Г.О. Снігур ${ }^{1,2,}$ I.C. Щербатенко ${ }^{1}$ I.O. Антіпов ${ }^{3}$

${ }^{1}$ Інститут мікробіології і вірусології ім. Д.К. Заболотного НАН України, вул. Академіка Заболотного, 154, Київ, 03143, Україна

${ }^{2}$ Київський національний університет імені Тараса Шевченка,

ННЦ “Інститут біології та медичини”, вул. Володимирська, 64/13, Київ, 01601, Україна ${ }^{3}$ Національний університет біоресурсів та природокористування Украӥни, відділ молекулярної біології, мікробіології та біобезпеки, вул. Героїв Оборони, 15, Київ, 03041, Україна

\section{Резюме}

Вступ. Бур'яни як резерватори патогенів, що згубно впливають на рослинний організм і значно погіршують кількість та якість врожаю, мають значний вплив на епідеміологію та екологію вірусів i, як наслідок, на місцеву економіку. Тому вони досліджуються у багатьох частинах світу. Метою даної роботи було дослідити поширення вірусів у рослинах глухої кропиви пурпурової (Lamium purpureum L.), широко розповсюдженої у міських та польових умовах Київської області. Методи.

1. Loebenstein G, Katis N. Control of plant virus diseases seed-propagated crops. Preface. Adv Virus Res. 2014; 90. p. 542. doi: 10.1016/B9780-12-801246-8.09985-6.

2. Plants of the World Online Lamium glaberrimum (K.Koch) Taliev. http://www.plantsoftheworldonline.org/taxon/urn:lsid:ipni.org:names: 448850-1

3. Kyrychenko A, Shcherbatenko I, Mishchenko L. BCMV-ukr: isolate of Bean common mosaic virus revealed in Ukraine. Arch Phytopath Plant Protect. 2019; 52(11-12):1005-1017.

4. Antipov I, Spyrydonov V, Melnychuk M. The development of diagnostic real time PCR system for detection of PVX, PVY, PVM, PVS Ukrainian isolates. "Scientific reports of nules of Ukraine". 2007; 3(8). http://nd.nubip.edu.ua/2007-3/07aiopui.pdf

5. Antipov IO. [Biotechnological aspects of molecular diagnostics of latent potato viral infection
Польові дослідження, візуальна діагностика, біологічне тестування вірусу, імуноферментний аналіз (ІФА), полімеразна ланцюгова реакція зі зворотною транскрипцією (RT-PCR). Результати, отримані у дослідженні, свідчать про важливе значення рослин Lamium purpureum L. як альтернативних хазяїв економічно-значущих збудників вірусних хвороб картоплі та інших овочів. За результатами серологічних та молекулярних досліджень встановлено, що рослини глухої кропиви пурпурової одночасно інфіковані X-, Y-, М- та $\mathrm{S}$-вірусами картоплі. Отримані результати свідчать про важливу роль губоцвітих роду Lamium як потенційного джерела вірусної інфекції в насадженнях овочів або декоративних рослин. Наше дослідження $\epsilon$ першим повідомленням про природне інфікування рослин Lamium purpureum L. M- вірусом картоплі та S- вірусом картоплі у Центральній Європі. Висновки. Нами вперше було показано, що глуха кропива пурпурова може слугувати альтернативним хазяїном змішаної інфекції вірусами, що належать до різних родин: Alphaflexiviridae, Betaflexiviridae та Potyviridae.

Ключові слова: Lamium purpureum L., кропива глуха пурпурова, альтернативні хазяї, X- вірус картоплі, Y- вірус картоплі, М- вірус картоплі, Sвірус картоплі.

(Solanum tuberosum L.)]. Abstract of the dissertation..... cand. agricultural Sciences: 03.00.20 2008. Ukrainian.

6. Milne RG. Electron microscopy of in vitro preparations. In: Diagnosis of Plant Virus Diseases. Matthews REF, editor. 1993; p. 215-252.

7. Saitou N, Nei M. The neighbor-joining method: A new method for reconstructing phylogenetic trees. Molecular Biology and Evolution. 1987; 4:406-425.

8. Jukes TH, Cantor CR. Evolution of protein molecules. In: Mammalian Protein Metabolism. Munro HN, editor, Academic Press, New York. 1969; pp. 21-132.

9. Fuentes S, Gibbs AJ, Hajizadeh M, Perez A, Adams IP, Fribourg CE, Kreuze J, Fox A, Boonham N, Jones RAC. The Phylogeography of Potato Virus X Shows the Fingerprints of Its Human Vector. Viruses. 2021; 13:644. doi: 10.3390/ v13040644 
10. Naveed Kh, Abbas A, Amrao L. Potato virus Y: An evolving pathogen of potato worldwide. Pakistan J Phytopath. 2017; 29:187-191. doi 10.33866/phytopathol.029.01.0310.

11. Nie B, Singh M, Murphy A, Sullivan A, Xie C, Nie X. Response of Potato Cultivars to Five Isolates Belonging to Four Strains of Potato virus Y. Plant Disease. 2012; 96:1422-1429. doi: 10.1094/PDIS-01-12-0018-RE.

12. Chaudhary P, Kumari R, Singh B, Hallan V, Nagpal AK. First report of potato virus $M$, potato virus $\mathrm{Y}$ and cucumber mosaic virus infection in Solanum nigrum in India. J Plant Pathol. 2019; 101:419. doi: 10.1007/s42161-018-0194-8.

13. Eskarous JK, Habib HM, Kishtah AA, Kistah AA, Ismail MH. A strain of Potato virus $\mathrm{Y}$ isolated from Solanum nigrum var. judaicum in Egypt. Phytopathol Mediterr. 1983; 22:53-58.

14. Krishna R, Srivastava KM, Singh BP. Carriage of a distinct isolate of Potato virus Y in Solanum nigrum L. Curr Sci. 1979; 48:701-770.

15. Antipov IO, Spyrydonov V, Melnychuk MD. Phylogenetic analysis of capsid protein genes of Ukrainian potato viruses isolates. Scientific Bulletin of Uzhhorod University. Series "Biology". 2007; 20:220-225.

16. Kaliciak A, Syller J. New hosts of Potato virus $\mathrm{Y}$ (PVY) among common wild plants in Europe. Eur J Plant Pathol. 2009; 124:707-713. doi: 10.1007/s10658-009-9452-0.

17. Yun WS, Jung HW, Oh MH, Hahm YI, Kim KH. Variation of potato virus $\mathrm{Y}$ isolated from potato, tobacco, pea and weeds in Korea on the C-terminal region of coat protein gene and 3' non-translated region. Plant Pathol J. 2002; 18(3):130137.

18. Kenneth M Smith. A text book of plant viral diseases, 3rd edition, ElsevierInc, New York. 2012; p. 694 .

19. Gadhave KR, Gautam S, Rasmussen DA, Srinivasan R. Aphid Transmission of Potyvirus: The Largest Plant-Infecting RNA Virus Genus. Viruses. 2020; 12(7):773. doi: 10.3390/v12070773.

20. Chiunga E, Valkonen JPT. First Report of Five Viruses Infecting Potatoes in Tanzania. Plant Dis. 2013; 97(9):1260. doi: 10.1094/PDIS-0213-0143-PDN.
21. Hameed A, Iqbal Z, Asad S, Mansoor S. Detection of Multiple Potato Viruses in the Field Suggests Synergistic Interactions among Potato Viruses in Pakistan. Plant Pathol J. 2014; 30(4):407-415. doi:10.5423/PPJ.OA.05.2014.0039.

22. Fox A, Collins L, Macarthur R, Blackburn L, Northing $\mathrm{Ph}$. New aphid vectors and efficiency of transmission of Potato virus A and strains of Potato virus Y in the UK. Plant Path. 2017; 66(2):325-335.

23. Lacomme C, Glais L, Bellstedt D, Dupuis B, Karasev A, Jacquot E, editors. Potato virus Y: biodiversity, pathogenicity, epidemiology and management. Springer, Cham. 2017; pp. 141176. doi: 10.1007/978-3-319-58860-5-6.

24. Bešta-Gajević R, Jerković-Mujkić A, Pilić S, Stanković I, Vučurović A, Bulajić A, Krstić B. Lamium maculatum is a Natural Host for Cucumber mosaic virus. Plant Dis. 2013; 97(1):150. doi: 10.1094/PDIS-08-12-0717-PDN.

25. Chatzivassiliou EK, Mpoumpourakas I, Drossos E, Eleftherohorinos I, Jenser G, Peters D, Katis NI. A different prevalence of weeds susceptible to tomato spotted wilt virus in tobacco and greenhouse cultivated crops in Greece. In: Recent progress on tospovirus research. Peters D, Golbach R, editors. Wageningen Agricultural University, Section Virology. 1998; p. 98.

26. Chatzivassiliou EK, Boubourakas I, Drossos E, Eleftherohorinos I, Jenser G, Peters D, Katis NI. Weeds in greenhouses and tobacco fields are differentially infected by Tomato spotted wilt virus and infested by its vector species. Plant Dis. $2001 ; 85: 40-46$.

27. Dikova B. Weeds in sugar-beet crops as virus hosts. Biotechnology and Biotechnological Equipment. 1993; 7(3):32-37. doi: 10.1080/ 13102818.1993 .10819423$.

28. Jorda C, Ortega A, Juarez M. New hosts of tomato spotted wilt virus. Plant Dis. 1995; 79:538.

29. Kil EJ, Park J, Lee H, Kim J, Choi HS, Lee KY, Kim CS, Lee S. Lamium amplexicaule (Lamiaceae): a weed reservoir for tomato yellow leaf curl virus (TYLCV) in Korea. Arch Virol. 2014; 159(6):1305-1311. doi: 10.1007/s00705-0131913-2. 
30. Lovisolo O. Virus e piante spontanee. Il Mosaico lieve dellamium nuovo virus di tipo maculatura anulare. Boll Staz Pat VegRoma III ser. 1958; 15:89-137.

31. Panno S, Ferriol I, Rangel EA, Olmos A, Han C-G, Martinelli F, Rubio L, Davino S. Detection and identification of Fabavirus species by onestep RT-PCR and multiplex RT-PCR. J Virol Meth. 2014; 197:77-82. doi: 10.1016/j.jviromet.2013.12.002

32. Parrella G, Gognalons P, Selassie KG, Vovlas C, Marchoux G. An update of the host range of tomato spotted wilt virus. J Plant Path. 2003; 85(4):227-264.

33. Rangel EA, Ferriol I, Panno S, Davino S, Olmos A, Rubio L. The complete genome sequence of Lamium mild mosaic virus, a member of the genus Fabavirus. Arch Virol. 2013; 158:2405. doi: 2408. 10.1007/s00705-013-1732-5.

34. Stobbs LW, Broadbent AB, Allen WR, Stirling AL. Transmission of tomato spotted wilt virus by the western flower thrips to weeds and native plants found in southern Ontario. Plant Disease. 1992; 76:23-29.
35. Tomlinson JA, Carter AL, Dale WT, Simpsom CJ. Weed plants as sources of cucumber mosaic virus. Ann Appl Biol. 1970; 66:11-16. doi: 10.1111/j.1744-7348.1970.tb04597.x.

36. Yamasaki S, Okazaki S, Okuda M. Temporal and spatial dispersal of Melon yellow spot virus in cucumber greenhouses and evaluation of weeds as infection sources. Europ J Plant Path. 2012; 132(2):139-177.

37. Zhang L, Lockhart B, Dahal G, Olszewski N. Studies on biology and genomic characterization of a caulimo-like virus associated with a leaf distortion disease of Lamium maculatum. Arch Virol. 2008; 153(6):1181-1184. doi: 10.1007/ s00705-008-0093-y.

38. Zitter TA. A Checklist of Major Weeds and Crops as Natural Hosts for Plant Viruses in the Northeast. Vegetable MD online. Department of Plant Pathology, Cornell University, Ithaca, NY, New York. (Date of access: 20.03.2021) https:// www.vegetables.cornell.edu/pest-management/ disease-factsheets/a-checklist-of-major-weedsand-crops-as-natural-hosts-for-plant-viruses-inthe-northeast/

Received 5.09.2021 